\title{
Award-winning papers in 2015
}

Papers published in Engineering History and Heritage are eligible for awards from the Institution of Civil Engineers. Papers from any of the ICE journals can be nominated for several awards. In addition, each journal has awards dedicated to their specific subject area.

On Friday 7 October 2016, ICE president John Armitt presented awards to the following papers published in Engineering History and Heritage in 2015 The editorial panel nominated their best papers and an awards committee chaired by Nigel Wright allocated the awards.

\section{Benjamin Baker Medal}

The Benjamin Baker Medal, presented to the third best paper published in all the ICE journals, was awarded to Holzer and Veihelmann (2015).

\section{Abstract}

The three-hinged arch, while increasingly common in steel bridge construction from the 1860s, was introduced more reluctantly into masonry and concrete bridge building. However, by the end of the nineteenth century, it had found widespread application, particularly in Germany. Considerations of crack prevention as well as ease and consistency of the mechanical modelling of masonry arches were evidently the driving forces behind this development. The present paper describes the history of the hinged vaulted bridge, from the first suggestions by the eminent French engineer Jules Dupuit (published in 1870) up to the early years of the twentieth century. Particular attention is given to temporary and 'imperfect' hinges which may be neither visible nor active in the finished state of the bridge, and to the historic development and design of permanent hinges, outlining the range of constructive solutions the modern engineer may encounter when assessing the state of a late nineteenth century vaulted bridge.

\section{Thomas Telford Premium}

The Thomas Telford Premium Prize, presented for the best paper published in Engineering History and Heritage, was awarded to Sheard (2015).

\section{Abstract}

When James Newlands (1813-1871) arrived in Liverpool in 1847 to take up the newly created position of Borough Engineer, he formed, along with Dr William Henry Duncan (Medical Officer of Health) and Thomas Fresh (Inspector of Nuisances), Britain's first public health team. This was Liverpool's response to national and international perceptions of it as a dangerously unhealthy town. Frequent outbreaks of epidemic diseases and poor living conditions had created an 'urban penalty' - the price paid for its rapid uncontrolled expansion. Over the next 23 years, Newlands shaped this new role, defining its territory through Liverpool's ambitious programme of sanitary reform. He designed Britain's first purpose-built sewerage system and his holistic vision of sustainable urban living encompassed municipal baths and wash-houses, road planning, public parks and street lighting. Newlands' collaborations with other civil engineers, with Dr Duncan and Liverpool Town Council provide a fascinating and instructive case study on how expert advice is used in policy development. This paper illustrates how the relative professional status of medicine and engineering shaped the development of the discipline of public health. The challenges Newlands successfully addressed in mid-nineteenth century Liverpool - integrated urban design, adequate funding, multi-disciplinary team working - remain critical to urban health now.

\section{REFERENCES}

Holzer SM and Veihelmann K (2015) Hinges in historic concrete and masonry arches. Proceedings of the Institution of Civil Engineers - Engineering History and Heritage 168(2): 55-64, http://dx.doi. org/10.1680/ehah.14.00019.

Sheard S (2015) James Newlands and the origins of the municipal engineer. Proceedings of the Institution of Civil Engineers Engineering History and Heritage 168(2): 83-89, http://dx.doi. org/10.1680/ehah.14.00008. 